\title{
Representation of Multiculturalism In "Syair Nasihat" As an Alternative to Strengthen the United Nations
}

\author{
Asep Yudha Wirajaya ${ }^{1}$, Bani Sudardi ${ }^{2}$, Istadiyantha ${ }^{3}$, Warto $^{4}$, Miftah Nugroho $^{5}$ \\ Culture Studies Program, Postgraduate, Sebelas Maret University, Indonesia ${ }^{1,2,3,4}$, Indonesian Literature \\ Study Program, Faculty of Cultural Sciences, Sebelas Maret University, Indonesia ${ }^{5}$ \\ \{asepyudha@staff.uns.ac.id\}
}

\begin{abstract}
Excessive religious and regional fanaticism has become a threat to the unity and integrity of the nation. Therefore, we need to re-explore the values of local wisdom contained in ancient texts. One of them is "Syair Nasihat". This poem teaches about a peaceful life in the frame of diversity. Besides, it is also taught to build a sense of togetherness and tolerance between ethnic groups, races, and religions. Thus, digging back into local wisdom is expected to be an alternative to strengthen the sense of national unity and unity which is now starting to fade. The research method used is the philological method and the method of studying the text. The results of this research are forms of representation related to the values of multiculturalism contained in the $\mathrm{SN}$ text.
\end{abstract}

Keywords: Syair Nasihat, representation, multiculturalism, unity, and national unity

\section{Introduction}

Syair Nasihat is one of the classical Malay literary works which is full of advice for humans to achieve a happy life in this world and the hereafter [1]. Based on the information contained in the colophon and the manuscript protection sheet, it is known that this SN manuscript was found in the Bali region on 10 April 1857 AD, then by the local Regent, it was handed over to Batavia on 21 April 1857 AD [2]. This is of interest to many cultural researchers, including researchers of classical Malay manuscripts of the archipelago.

Given that Bali is an area dominated by Hinduism. However, it was found that classical Malay manuscripts were Islamic nuances, even containing the teachings of Wahdat al-wujud [3]-[6]. In this context, the existence of the SN text and its relationship with the Balinese Muslim community are things that need to be examined in more depth. At least, this study is expected to provide an overview and inspiration for the religious life that can coexist peacefully under the framework of Indonesian multiculturalism and diversity.

Such values are indispensable for the life of a postmodern society that is increasingly far from the essence of a religion. Religion is now only limited to a complimentary identity that has lost its spirit. As a result, religion is treated as nothing more than a status. Religion should be able to guide people to a better life, namely a life that is always shaded by the grace and pleasure of Allah SWT [7], [8].

Therefore, the study of the archipelago classical texts is one of the alternatives to re-express the wisdom values practiced by our ancestors in building harmony and harmonious relations between fellow religious communities [9], [10]. Hopefully, the results of this study, it can be 
used as a source of inspiration for the development of a complete Indonesian human being, which is advanced, modern, adaptive, but still based on divine and human values [7], [11], [12].

\section{Research Methods}

In general, this research is included in cultural studies research. The study of the culture of representation not only reflects in the symbolic form of "something" that exists in an independent object world, but the representation itself is constitutive of the meaning to be conveyed or fought for [13], [14]. Representation thus does not involve correspondence between sign and object, but rather creates "the representational impact of realism [13]-[15]. Therefore, research on culture is often considered parallel to the exploration of representational processes. Although culture is not just a question of representation, but also a matter of spatial arrangement and practice, there are strong arguments to support the view that it is the representational process that makes these practices meaningful and significant [13], [14].

The stages of this research begin with editing the SN text [9], [10], [16], then proceed with analysing the forms of multicultural representation contained in the SN text [3], [12], [17], [18]. It is with the hope that the forms of representation that have existed and have been done by our ancestors can be used as a source of inspiration for the lives of Indonesian people in this postmodern period. In this way, there will be a spirit of togetherness, a sense of unity and oneness among the nation's children [18].

\section{Results and Discussion}

\subsection{Brief History of Religious Conflict in the Archipelago}

Actually, conflicts with religious nuances have not only occurred recently but have also colored the journey of human civilization in the archipelago for a long time. However, in the heyday of Old Mataram (around the 7th - 8th century AD), there was a common awareness that living peacefully side by side with fellow human beings is a gift that must always be grateful for [19].

In fact, between the two dynasties, namely between Wangsa Sanjaya and Wangsa Syailendra, marriage was carried out as a form of engagement that was more "sacred" so that there was no longer any religious conflict. As a result, not long after, the Sriwijaya Kingdom was able to emerge as a large country capable of protecting the lives of all its people of different religions and beliefs [19]. This success then inspired the masters in the era of the Majapahit kingdom to confirm it as the country's motto, Bhinneka Tunggal Ika, which means "different but one thing"[20], [21].

The motto "Bhinneka Tunggal Ika Tan Hana Dharmma Mangrwa" actually comes from Kakawin Sutasoma, written by Mpu Tantular in Pupuh 139: 5 as follows.

Rwaneka dhatu winuwus wara Buddha Wiswa,

Bhinneki rakwa ring apan kena parwanosen,

Mangka ng Jinatwa kalawan Siwatatwa tunggal,

Bhinneka tunggal ika tan han dharmma mangrwa

Meaning: It is said that the forms of Buddha and Shiva are different. They are different. However, we can recognize the difference at a glance, without delving deeper into it because 
the truths taught by Buddha and Shiva are actually the same, one thing too. They are different or divided, but the essence is the same. Because there is no ambiguous truth.

If in the past the slogan had succeeded in uniting the two religions, namely Buddhism and Shiva in a peaceful and unifying life, even advancing the archipelago, then it would not be an exaggeration to adopt this slogan to unify the archipelago. Thus, it is not an exaggeration if the slogan is interpreted as "different but one thing" [20], [21].

However, peace is tarnished again, when there is a power struggle. Moreover, the struggle for power is dressed in the name of religion. It is as if all the foundations that have been built neatly from the 7 th century AD until the 14th century AD are falling apart. History records that the conflict between Sheikh Siti Jenar and the Guardian Council (walisongo) has not been completely resolved to this day. It is true that Sheikh Siti Jenar was executed because he was deemed to have taught a heretical sect, namely wahdat al-wujud. However, his followers still could not accept the verdict. They still believe that the teacher is not guilty [4]. In fact, some of Syekh Siti Jenar's followers migrated to Bali with the teachings of manunggaling kawula-Gusti or wahdat al-wujud [4].

In fact, the internal friction of Islamic figures at that time was based more on differences in thoughts (followers of) Syekh Siti Jenar who prioritized Islam from the perspective of makrifat logic (Islamic philosophy), while walisongo prioritized sharia (Islamic ritualism) [22]. On the other hand, walisongo is the main advisor of the Demak Bintoro Palace, so it is not surprising that the walisongo versions of Islam are more developed in the Islamic kingdom. Siti Jenar's version of Islam is relatively limited, but not a few Majapahit figures are included in this sect, such as Ki Kebo Kenongo (brother of Kebo Kanigoro) who is none other than Ki Ageng Pengging [4].

In this perspective, the spiritual movement of Siti Jenar is seen as having shaken the sociopolitical life of the Keraton Demak Bintoro. The religious interpretation carried out by Siti Jenar and her followers has led to the involvement of the Walisanga Council in the flow of the political conflict. Syekh Siti Jenar then alienated Ki Kebo Kenongo and Ki Ageng Pengging, both of whom felt entitled to the inheritance of the Majapahit throne which was already held by the Sultan of Demak. Then, the two camps built political-religious solidarity complete with their social networks. As a result, each party insists on its stand and interests [4].

Now, in the context of the spread of Islam in Bali, the common thread is clear: if Nirartha is a Muslim, then it is very possible that he belongs to Siti Jenar's group. This was reinforced by Nirartha's attitude who avoided the walisongo version of Islam. So, Nirartha fled to Bali not to avoid Islam, but to stay away from the walisongo versions of Islamization which was increasingly dominant in Java. Likewise, Nirartha (through Waturenggong) rejected the mission of Siti Fatimah, the delegation of Demak [23]. This means that Nirartha's refugee and rejection are essentially an extension of the Siti Jenar version of the conflict versus the Islamist version of Walisongo. In Java itself, the friction of the two Islamic camps even surfaced as an open resistance from Siti Jenar's followers against Demak, such as the defiance of Ki Kebo Kenongo / Ki Ageng Pengging / Joko Tingkir's father who refused to face the sultan at the Demak Palace, so he received a "death penalty" [4].

As a devotee of Siti Jenar, Nirartha also does not emphasize religious rituals but deals more with the thinking side of faith. The religion that was developed by Nirartha was more syncretic in plain view. If in Java the Javanese type of Islam developed with the substance "Eling" and "Manunggaling Kawula-Gusti", Nirartha also did the same thing while in Bali. Once again it should be noted that considering the background of the Shiva Buddhist community in Bali, including a fanatical group, even willing to flee from Java since the fall of Majapahit, it must be injected in terms of the substance of Islamic logic, but from a formal perspective, the ritual 
remains very thick with Hinduism. In subsequent developments, Javanese Islam increasingly shows its original Islamic face, while Balinese Islam (ala Nirartha) is, on the contrary, its Islamic face is fading away so that only the face of its Hindus [4], [23] remains.

In the mainstream understanding of Balinese Hindus, Nirartha is indeed considered a reformer, as when he created the concept of "Padmasana" which reunites "Tri Murti" in one place of worship so that Hindus can unite. This concept was later inherited as a place of worship at Jagadnatha Temple, a public temple that is not limited by village customary rules [4], [23]. If it is true that Nirartha is a Muslim, then the logic of justification that he built is an attempt to include the basic Islamic principles of Islamic tauhid (Oneness of God/monotheism side) where God is One in His Essence and Nature so that God cannot be divided (including the boundaries of place prayer) between Creator, Sustainer, and Destroyer.

He is Sang Hyang Widi Wasa. The concept of Tri Hita Karana (the concept of harmony with God, fellow human beings, and the universe) for example, is substantially not much different from Islamic teachings, namely in the concepts of "hablum mina'l-Lah" and "hablum minannas". These Nirartha-style reforms have made Balinese Hinduism very different from Hinduism in its native India. Because Nirartha emphasizes more on divine philosophy, Balinese (Hindu) ritualism has up to now completely no Islamic style, as is the very difference between the Kejawen style and the true Islam [4].

As a fellow Muslim, Nirartha did not advise Waturenggong to expel, let alone kill the 100 Muslim members of the defeated Demak expedition, but it was enough to just punish the leader. They were given real palms (a piece of Gelgel land and even added to the Kampung Lebah) and were given the freedom to practice their religion. Finally, after a long period, there was an acculturation of the Hindu - Muslim community, an adhesive culture was developed that emphasized equality and mutual respect and respect so that it was far from the seeds of "feud" [4].

The management of inter-religious plurality is neatly arranged through similarities without questioning the existence of differences. This very positive habit has been built since Dalem Watu Renggong. Even though the king was personally unwilling to become a Muslim [23], he is said to have always provided additional provisions for Muslims who were going to perform the pilgrimage to Mecca [4]. The reality of this Waturenggong - Nirartha attitude has placed Muslims in Gelgel in the first half of the 16th century AD in a situation of safe living. They developed and even expanded to other Klungkung areas, such as being given land by the puri in Kampung Jawa and Kampung Lebah [4].

In the second half of the 17th century AD in the Kingdom of Aceh, conflicts with religious nuances occurred again which originated from differences in views in the political field because they were related to issues of power. As a result, Islam was divided into Sunni and Shi'ah [24]. This conflict resulted in the burning of the works of wujudiyah murshids, murder, and slaughter of followers of the wujudiyah sect [5], [6].

This condition was exacerbated by the serious accusation that murshids of the wujudiyah sect were considered to be affiliated with the Shi'ah [6], [25], [26]. However, the wisdom of a murshid does not automatically make him think of taking revenge [27], [28]. Instead, he consistently makes works in which he teaches to stick to the teachings of love as the embodiment of God's grace to all beings on earth [5], [29]. One of them is Syair Advice (hereinafter abbreviated to $\mathrm{SN}$ ) which is full of wujudiyah Sufism messages.

\subsection{SN as a Representation of Multiculturalism}

$\mathrm{SN}$ is one of the classic Malay literary works found in Bali. This is based on the notes found on the cover page of the manuscript. This can be seen in the following figure. 


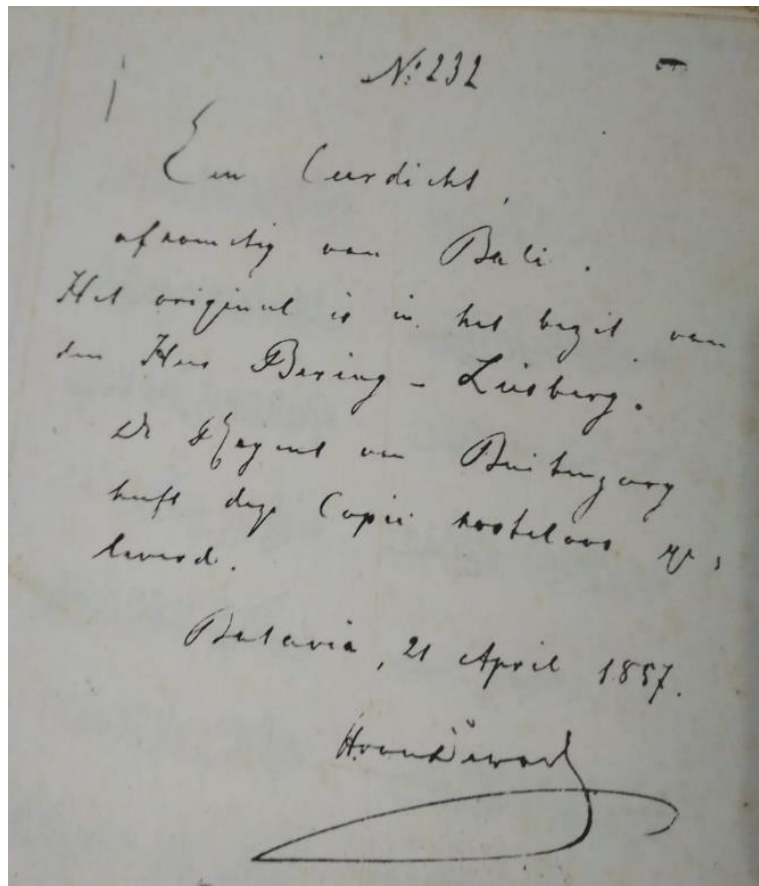

No: 232

Terjemahan:

Ada Sajak (Bersifat Ilmu)

Asal dari Bali

Asli tulisan ini ada di tangan Bapak Bering

Zuidberg

Dan Regent dari Buitenarg

Serahkan kopi ini secara

cuma-cuma

Batavia, 21 April 1857 M

Translate:

There is Poetry (Knowledge)

Origin from Bali

The original of this paper is in the hands of Mr. Bering Zuidberg

And Regent of Buitenarg

Hand over this copy free

Batavia, 21

April 1857 M

Fig 1. Manuscript Cover Sheet Protector

Based on the information from the manuscript cover page, it is known that this copy of the SN manuscript was actually found in Bali, then it was handed over to Batavia free of charge or free of charge. The manuscript was received in Batavia on 21 April 1857 AD or 26 Sya'ban $1273 \mathrm{H} \mathrm{[30].} \mathrm{That} \mathrm{is,} \mathrm{it} \mathrm{only} \mathrm{took} 11$ days from the time the manuscript was copied. This can be seen in the colophon quotation of the manuscript as follows.

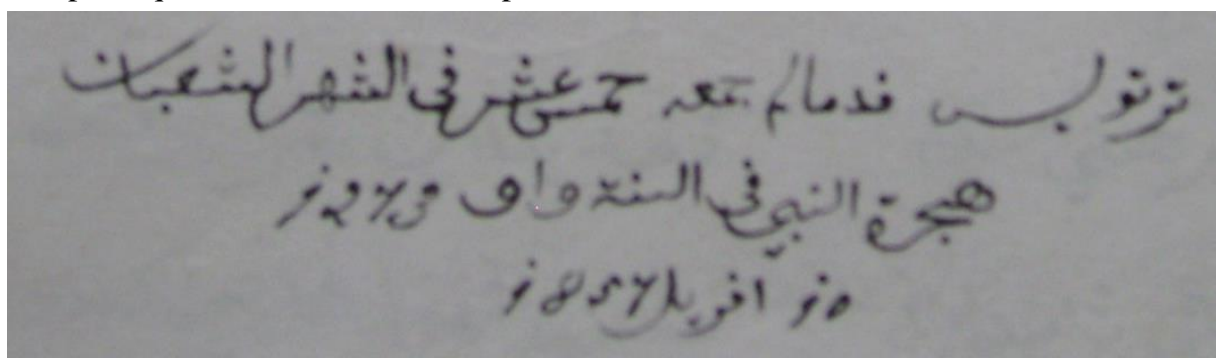

Fig 2. Manuscript Colophon

\section{Transliterasinya:}

"Tertulis pada malam Jumat, khamis, asyar fi syahru as-Sya'ban

Hijratu an-Nabi fi as-sanati wawu $1273 \mathrm{H}$

10 April 1857 M"

\section{Translate:}

"It was written on Friday night, to be precise Thursday, at the time of Asar in the month of Sha'ban, the year of Wawu in $1273 \mathrm{AH}$.

April 10, 1857 AD" 
Thus, based on the information contained in the colophon, it is known that the copying of this SN text was completed on 10 April 1857 AD or 15 Sha'ban 1273 H [30]. Then, this manuscript was sent to Batavia and received on April 21, 1857 AD.

Based on these data, it can be understood that the logic and phenomenon of accumulation between communities and cultures of different religions are of course not unique to Java, but also appear to be prevalent in Bali. Understandably, Islam which developed in various regions in Bali at the beginning was also full of acculturation nuances. Indeed, in religious substance, the values of the creed are still firmly held by this Islamic community, but in the cultural face there are many open interactions. This means that each community absorbs each other so that there is a kind of approach process. Therefore, it can also be understood if the Hindus had a special name for the Muslims at that time by using the word: "Nyamo Slam" aka "Brother of Islam". "Nyamo/Saudara", because in the genealogical reality between the Hindu and Muslim communities there is a family connection. "Slam/Islam", because in their religious reality they are different from Hindu religious beliefs [4], [23].

The Muslims of the old kampungs have historically been known as honest people and have kept their promises. This assumption has existed since the time of their ancestors. In fact, because of the adherence to this promise (loyalty), Muslims were then used as a living fortress or elite royal troops (Puri) so that the relationship between the people of Muslim villages and the kingdom/Puri was very good, even today. In the social context, the agreement not to interfere with each other between believers of other faiths, the Islamic community has never denied it, so that Hindus in that place end up looking positively towards Islam. This is because it has been proven that Islam can coexist with the surrounding community for generations. Once again, it can be understood if Muslims are considered as brothers of Hindus through the term "Nyama Slam" earlier [4], [23].

In the context of the old era cultural sociology, what manifested in Bali was the Balinese Muslim community and Balinese Hinduism and not in terms of indigenous people and migrants because historically both were migrants and only had different periods of arrival. Therefore, the responsibility for developing the region ultimately becomes a shared responsibility and concern. This is evident when Bali has to face enemies from outside, then everything becomes a shared responsibility. In that context, history has noted that when Bali was threatened by Dutch colonialism, for example, Muslims - Hindus worked for hand in hand to defend their territorial independence [4], [23]. It is also contained in the SN stanza as follows:

hendaklah orang yang dijadikan kapitan mengembangkan payung di tangannya rotan jikalau kurang-kurang ingatan kelak menjadi tentaranya setan let the captain

develop a rattan umbrella in her hand if you lack memory

$[2, p .10]$ later became Satan's army p. 10]

The mention of the word "Kapitan" in the stanza is a borrowed element from the Dutch language. This indicated that the Dutch were already in Bali at that time. Besides, it also implies that a "captain" should not be just a position in the military world, but also demonstrate the ability to lead both himself and his subordinates. If a "captain" is unable to control himself, he will become Satan's army. So, the author of this SN text expressly reminds Dutch leaders in particular and leaders in general.

However, if the warning is not heeded at all, then every Muslim must fight and fight against Satan and his troops, including Dutch colonialism. Therefore, the decision of the Muslim community in Bali to fight against Dutch colonialism was not only based on elements of historical, cultural closeness but was also based on the belief in carrying out the orders of Allah. 
This should be built in the context of caring for Indonesia in the frame of diversity and multiculturalism.

Thus, codicological and tectological, it is increasingly clear that SN's existence as one of the classical Malay works instills and teaches multiculturalism values. By building this awareness, hopefully, there will be no more power conflicts wrapped in the name of religion. Because if this still happens, then we will continue to wallow in the same mistakes and as if we have never learned from the history of Nusantara civilization.

\section{Conclusion}

Based on the previous description, it can be concluded that $\mathrm{SN}$ is a classic Malay literary work that contains multiculturalism values that are still relevant to postmodern life today. This can be seen both through the quotations of his verses which always teach love for fellow humans as a form of realization of his belief in Allah SWT, and through its codicological aspects which explicitly show that the SN manuscript was indeed created and written in the nuances of a life full of mutual respect, appreciate, and accept each other's differences. Differences are not actually a barrier for fellow human beings to be able to live peacefully side by side in order to achieve happiness.

Therefore, it is necessary to encourage studies of ancient texts so that the treasures of our ancestors' thoughts can be revealed which can be used as an alternative source of inspiration for the problems the nation is currently facing.

\section{References}

[1] A. Y. Wirajaya, Poetic Aesthetics of Classical Malay Literature. Surakarta: Library Oasis, 2019.

[2] Anonim, Syair Nasihat. Jakarta: Perpustakaan Nasional Republik Indonesia, 1857.

[3] et. al. Wirajaya, Asep Yudha, Textology: Studying the Treasures of Classical Malay Literature. Surakarta: Library Oasis, 2020.

[4] D. Mashad, Balinese Muslims: Recovering Lost Harmony. Jakarta: Pustaka Al-Kautsar, 2014.

[5] Miswari, Wahdah al-Wujud: Concept of Unity of Being between Servant and God according to Hamzah Fansuri. Yogyakarta: Basabasi, 2018.

[6] A. Hadi, Oppressed Sufism: A Hermeneutic Study of Hamzah Fansuri's Works. Jakarta: Paramadina, 2001.

[7] K. Hidayat, Religion for Civilization: Grounding Religious Ethos in Life. Tangerang Selatan: Pustaka Alvabet, 2019.

[8] Hamka, Modern Sufism: Happiness is Close to Us - It is within Us, 12th ed. Jakarta: Republika Penerbit, 2020.

[9] A. Ikram, Introduction to Philological Research. Jakarta: Archipelago Textbook Society, 2019.

[10] O. Fathurahman, Indonesian Philology: Theory and Method. Jakarta: Prenadamedia Group and UIN Jakarta, 2015.

[11] K. Hidayat, Understanding the Language of Religion: A Hermeneutic Study. Jakarta: Paramadina, 1986.

[12] A. Y. Wirajaya, Textology: An Introduction. Surakarta: Awan Pustaka, 2015.

[13] S. Waluyo, Arya Penangsang: A Historical Portrait of the Battle of Coastal Java Versus Inland Java. Yogyakarta: Ombak, 2020.

[14] C. Hight, "Review: Cultural Studies: Theory and Practice," Media Int. Aust. Inc. Cult. Policy, 2001.

[15] S. Dobscha and P. Alasuutari, "Researching Culture: Qualitative Method and Cultural Studies," J. Mark. Res., 1997.

[16] E. Djamaris, Philology Research Methods. Jakarta: Monasco, 2002. 
[17] A. Y. Wirajaya, "Palembang's Transformation into a Multicultural City: A Reflection on the Text of the Simbur Cahaya Law and Tuhfah ar-Raghibin,” Shahih, vol. 3, no. 1, pp. 33-45, 2018.

[18] A. Wirajaya, M. Nugroho, S. Dasuki, T. Satya Dewi, and H. Syukri, "Revitalizing the Concept of Multiculturalism in the Malay Manuscripts as Efforts to Strengthen National Unity," in Proceedings of the Proceedings of the Third International Seminar on Recent Language, Literature, and Local Culture Studies, BASA, 20-21 September 2019, Surakarta, Central Java, Indonesia, 2020.

[19] "Gus Muwafiq - ASAL USUL TANAH JAWA - YouTube." [Online]. Available: https://www.youtube.com/watch?v=ab-rmqFVNkQ. [Accessed: 29-Oct-2020].

[20] "Bendera dan Semboyan Negara, Warisan Majapahit yang Dipertahankan - Suaramerdeka." [Online]. Available: https://www.suaramerdeka.com/kesehatan/baca/739/bendera-dan-semboyannegara-warisan-majapahit-yang-dipertahankan. [Accessed: 29-Oct-2020].

[21] P. Suparlan, "Menuju Masyarakat Indonesia yang Multikultural,” Antropol. Indones., 2014.

[22] T. Izutsu, Sufisme: Samudra makrifat Ibn ’Arabi. Jakarta: Mizan Publika, 2016.

[23] D. S. dan Y. I. Amellia, Bali 1842: Lets Over Balie en Deszelfs Bewoners. Jakarta: Perpustakaan Nasional Republik Indonesia, 2012.

[24] S. H. Nasr, Sufism: Past and Present. Yogyakarta: IRCiSoD, 2020.

[25] D. Lombard, Kingdom of Aceh: the era of Sultan Iskandar Muda (1607 - 1636). Jakarta: Popular Libraries Gramedia - Forum Jakarta-Paris - École française d'Extrême-Orient, 2014.

[26] M. W. Yahya, Uncovering the Spiritual Secret of Sheikh Abdul Muhyi: Tracing in the Footsteps of Archipelago Sufi Figures in the XVII \& XVIII Century. Bandung: Refika Aditama, 2007.

[27] Z. Yani, “Analisis Tematik terhadap Syair Burung Pingai Karya Hamzah Fansuri,” Penamas Balai Litbang Agama Jakarta, 2009.

[28] Syafrial, Hadi Rumadi, Oki Rasdana, "The Aesthetic of Mantra as Medical Treatment in Malay Riau," in International Seminar and Annual Meeting BKS - PTN West Region, Fields of Language, Literature, Arts, and Culture, 2018.

[29] S. Hicks, "The maligned, maltreated madu: Female experiences of polygyny in three romantic Syair," Indones. Malay World, 2008.

[30] "Pengubah Tanggal Masehi dari/ke Hijriyah - Alhabib." [Online]. Available: https://www.alhabib.info/kalender-islam/pengubah-tanggal-lahir-kalender-hijriyah.htm. [Accessed: 29-Oct-2020]. 